\title{
9: 131984807-131765053
}

National Cancer Institute

\section{Source}

National Cancer Institute. 9: 131984807-131765053. NCI Thesaurus. Code C41999.

Physical location of CRSP8_Gene 